\title{
Assessing the potential economic benefits to farmers from various GM crops becoming available in the European Union by 2025: results from an expert survey
}

Article

Accepted Version

Creative Commons: Attribution-Noncommercial-No Derivative Works 4.0

Jones, P. J., McFarlane, I. D., Park, J. R. and Tranter, R. B. (2017) Assessing the potential economic benefits to farmers from various GM crops becoming available in the European Union by 2025: results from an expert survey. Agricultural Systems, 155. pp. 158-167. ISSN 0308-521X doi: https://doi.org/10.1016/j.agsy.2017.05.005 Available at https://centaur.reading.ac.uk/71362/

It is advisable to refer to the publisher's version if you intend to cite from the work. See Guidance on citing.

To link to this article DOI: http://dx.doi.org/10.1016/j.agsy.2017.05.005

Publisher: Elsevier

All outputs in CentAUR are protected by Intellectual Property Rights law, including copyright law. Copyright and IPR is retained by the creators or other copyright holders. Terms and conditions for use of this material are defined in the End User Agreement. 


\section{www.reading.ac.uk/centaur}

\section{CentAUR}

Central Archive at the University of Reading

Reading's research outputs online 


\section{Assessing the potential economic benefits to farmers from various GM crops becoming}

2 available in the European Union by 2025: results from an expert survey

3 I. Introduction

4 Evidence is being presented in many quarters that genetically modified (GM) crops have

5 delivered net benefits for farmers, both small and large scale, and consumers, in the countries

6 where cultivation has been permitted (e.g. Brookes \& Barfoot, 2016 and James, 2014).

7 Depending on the crop and trait, these benefits might be agronomic, economic and/or

8 environmental in nature, resulting from yield improvements, better management of pests and

9 diseases, reduced input use and nutritional improvements. While there are a growing number

10 of commercially-grown GM crops in the world, only one GM crop is currently permitted for

11 cultivation in the European Union (EU) i.e. Bt maize. While Bt maize cultivation occurred in

12 five EU countries in 2014, the areas cultivated were very small, with only Spain and Portugal producing more than a few thousand hectares i.e. 131,537 ha (MAGRAMA, 2014) and 8,542 ha (Ministry of Agriculture and Sea of Portugal, 2014) respectively. As the House of Commons (2015) points out, the fact that there is only one GM crop approved for cultivation is largely due to the extremely slow and cumbersome EU GM approvals process, which requires majority member state approval in the European Council, resulting in an effective moratorium on further authorisations in the EU. As a consequence of this extremely arid policy environment, private sector investment in GM technology has moved out of the EU and consequently there is very little research being undertaken specifically focused on the needs of EU agriculture or consumers. It is, therefore, unsurprising to note that some commercial biotech companies have started to withdraw pending applications for EU authorisations for GM technologies that they have developed (EC, 2016a). 
However, this 'informal' moratorium on GM authorisations within the EU might soon be lifted, as a consequence of recent changes to legislation. Directive (EU) 2015/412 of the European Parliament and of the Council of 11 March 2015, amending Directive 2001/18/EC, provides the means for the Member States to restrict or prohibit, on certain grounds, the cultivation of genetically modified organisms (GMOs) in their territory, even when these have been judged by the EU's regulators to pose no risk to human health or the environment (European Parliament and Council, 2015). Allowing Member States to unilaterally ban GM cultivation may not sound like much of a breakthrough for GM authorizations, but the rationale for allowing Member States to 'opt out' of GM cultivation in this way, is that they will not need to block agreement on GM authorisations within the European Council to maintain their own GM-free status, thereby making EU-level authorisations easier to obtain.

\section{Outside of the EU, the development pipeline continues to produce new} commercialized GM crops. The USDA Animal and Plant Health Inspection Service (APHIS), which regularly publishes lists of successful petitions for unregulated release of GM events into the environment in the USA, announced in September 2015 that the 117th such petition, for a potato with blight-resistance (Pathogen Tolerant - PT) and other properties, was approved for trials (APHIS, 2015). While there has been no incentive for commercial biotech companies to develop crop-trait combinations targeted at agronomic conditions prevailing in Europe, Stein and Rodriguez-Cerezo (2009) have noted that some GM crops already commercialized outside the EU, or within the development pipeline, are both agronomically suitable and may offer potential benefits for farmers or consumers in the EU. With a potential unblocking of the EU GM crop authorisation process now a distinct possibility, leading to some 
countries in the EU (such as an independent post-Brexit UK) considering adoption of

GM crops, it is timely to review the GM crop-trait combinations that were currently,

or soon to be available, to identify their suitability for cultivation in the EU and examine the nature of the benefits that they might offer to either farmers and/or consumers.

Almost all past evaluations of the benefits offered by potential uptake of GM technologies in the EU have focussed on the farm-scale economic benefits offered by the most common GM crops (soybean, maize, cotton and canola) and traits (herbicide tolerance [HT] and insect resistance [IR] (Kathage et al., 2016). This concentration on crop-trait combinations already commercialised (see, for example, Demont and Tollens, 2004; Demont et al., 2007; Brookes, 2007; Demont et al., 2008; Dillen et al., 2009; Carpenter, 2010) has occurred for the practical reason that these cases provide some data on the benefits obtained from adoption available from non-EU settings, or at least from field-scale trials. As Kathage et al. (2016) pointed out, the availability of data remains the primary constraint to evaluation of the impacts of GM crops in the EU setting. An exception to this trend is Flannery et al. (2004) who included some 'hypothetical' crop-trait combinations in a benefits evaluation for Ireland. For the study detailed here, it was concluded that because the policy and regulatory changes required to 'open up' EU member states to GM crop production was likely to take a number of years, the scope of this analysis could not be confined to GM technologies already commercialised, but must also have to take into account crop-trait combinations still in development, that are likely to be available in the near future, say by 2025. The novel approach taken in the evaluation presented here i.e. extending the scope of the analysis to include GM crops not yet commercialised, presented an obvious methodological problem: that of obtaining data on the likely benefits from uptake of crops where no 
observational data were available. Past approaches to estimate likely benefits from GM crops grown in the EU have involved extensive surveys of non-EU production thus providing data for transfer into the EU context. When such approaches were not possible i.e. where only limited data were available, modelling exercises have been undertaken (see, for example, Demont and Tollens, 2004), sometimes involving statistical approaches, such as stochastic simulation techniques to overcome concerns about the accuracy or representativeness of the data. However, for most crops considered here, because they are yet to be commercialised, no data are available at all. To overcome this problem, we adopted the only remaining approach that could supply credible benefits data - stakeholder consultation, where a panel of experts in GM technologies provided estimates of likely future benefits of GM adoption.

This approach was also applied to crop-trait combinations that are commercialised outside of the EU, as these individuals have the appropriate knowledge to make necessary adjustments to non-EU data to account for differences in agronomic conditions between the data donor and recipient countries. Stakeholder consultation seemed to provide a consistent data generation process for all cases i.e. for technologies already developed and those still in the development pipeline whether for input or output traits. The approach:

- could be informed by any economic evaluation that exists;

- could make adjustments to non-EU data to account for EU agronomic conditions; and - could generate new 'notional' data where no observational data currently existed.

To maximise the quality of the data derived from the survey of stakeholders, the study employed the so-called 'Delphi' technique, developed at the RAND Corporation (Dalkey and Helmer, 1963). The Delphi technique takes information from a panel of well-informed individuals and builds these data into a consensus about possible future change or developments (Hsu and Sandford, 2007; Linstone and Turoff, 1975; Martino, 1993; Young 
and Jamieson, 2001). The key characteristic of the Delphi process is that data gathering is an iterative process, punctuated by feedback of the group results to all contributing individuals. In light of this feedback individuals are then permitted to amend their judgements until an acceptable measure of consensus is reached. Multiple iterations are sometimes required to derive an acceptable level of consensus. Data can be collected in a group setting, or anonymously, as this is an effective way of reducing the biasing effects of dominant individuals operating in group settings such as focus groups (Dalkey, 1972; Scott, 2011).

The Delphi technique has become a well-accepted means of using expert opinion to help anticipate future events in many technological, social and political fields. It has also been used to explore a diverse range of issues in the realm of food and agriculture, for example: policy forecasting (Fearne, 1986); anticipating biotechnology trends (Menrad et al, 1999); food supply chain developments (Ilbery et al, 2004); scoping the role of agriculture in flood management (Kenyon et al, 2008); analysis of the drivers of past Common Agricultural Policy (CAP) reform rounds (Cunha and Swinbank, 2009); examining sustainable upland rural estate management (Glass et al, 2013); prioritisation of management strategies to control zoonotic diseases (Stebler et al, 2015); and evaluation of vegetation management strategies under electric power lines (Dupras et al, 2016).

In this paper, we report the results of a global Delphi survey consultation into the potential agronomic and economic benefits that 12 prospective GM crop-trait combinations might offer to EU farmers and/or consumers. In addition, the paper also addresses the question of the significance of any estimated benefits identified i.e. asking the question 'how much difference would these benefits make to the competitiveness of adopters compared to non- 
adopters?' Past experience suggests that once these technologies are licensed for use in a country, if they offer any worthwhile benefit, the vast majority of farmers quickly adopt them. This assumption is based on observation of the very rapid and near complete market penetration of Herbicide Tolerant (HT) canola in Canada (James, 2014). Some past studies modelled the likely rate of uptake of GM technologies in various countries (e.g. Dillen et al., 2009) but these estimates were based on simple assumptions of the speed and nature of GM adoption patterns of similar GM technologies in non-EU countries. As such approaches can be criticised, the simplifying assumption was made that, for each crop trait included in this evaluation, maximum penetration had been achieved. For this reason, rather than examine the potential benefits received by individual farmers of adoption of these GM technologies, it made more sense to explore the issue of the competitive advantage conferred on countries that adopt them, compared to competitors that do not. To do this, the input and output impacts of the GM traits estimated in the stakeholder consultation were applied to standard northern EU countries, is assessed. The choice of the UK as the experimental platform for this competitiveness analysis is made more pertinent by the recent Brexit vote in the UK. As a consequence of this public vote, the UK will find itself outside of the EU GM licensing therefore, likely that the effective moratorium on GM licensing seen in the EU will not be 
the adoption of GM technologies would have on the relative competitiveness of the UK agriculture sector.

\section{Method}

While there were many crop-trait combinations in the market, or under development, not all of these would be suitable for EU agronomic conditions, or offer traits that would provide benefits in the EU. A literature review was used to select appropriate candidates from within this population of options through the identification of the need for a trait to meet a particular EU agronomic challenge or, by identifying a particular crop-trait combination already discussed in the literature which might offer benefits in the EU context, for example by helping to overcome a common EU pest problem or climatic limitation (see Ricroch \& Hénard-Damave, 2016; Hefferon, 2015; De Steur et al., 2015; and the GM Foods Platform (FAO, 2015)). Using these selection criteria, the EU FP7 AMIGA project team selected relevant crop-trait combinations from three official government databases of applications for release of GM material to the environment: the USDA APHIS database of field tests of GM crops (USDA, 2015); the EU GMO Register (JRC, 2015); and the Australian Applications and Authorisations for Dealings involving Intentional Release (DIR) database (OGTR, 2015).

The subset of crop-trait combinations selected is presented in Appendix 1, which classifies crop-trait combinations into two broad types. First, those that have already secured USDA de-regulated status and therefore either have, or legally could be, commercialised, and second, those still undergoing trials and awaiting de-regulation.

The traits identified in Appendix 1 are expressed as broad phenotype classes. However, within these broad classes, several specific technologies might exist. For example, the phenotype class HT captures multiple technologies providing tolerance to a number of 
different herbicide compounds. Because of this, the counter-intuitive phenomenon is seen in Appendix 1 that field trials are still being undertaken in a phenotype class even though some representatives of that class have already achieved USDA deregulated status. Continuing the use of the HT class as an example, this occurs where developers are trying to produce HT crops tolerant either to different herbicides, or multiple herbicides as stacked traits. In the APHIS database, not only have some individual technologies been de-regulated, but they have also been commercialised, and so are currently available for uptake by farmers in some countries. To illustrate, $67 \%$ of the area of maize grown in the USA in 2013 was stacked herbicide tolerant/insect resistant (HT/IR) (Fernandez-Cornejo et al, 2014), while drought tolerant maize was grown on $275 \mathrm{k}$ ha $(0.3 \%$ of the total area) in the USA in 2014 (James, 2014).

The shortlisted crop-trait combinations identified by means of this review process, had the following characteristics:

- the technology had either achieved USDA de-regulated status, or was undergoing field trials towards that objective, either in the USA, the EU or Australia;

- the technology is agronomically suitable for EU agriculture; and

- examples of this technology are either already available in the global marketplace, or stand a very good chance of being so by 2025 .

The subset of 12 crop-trait combinations were further classified on the basis of whether their traits offer benefits on the input side to the farmer or grower, i.e. improved agronomic properties or, on the output side, that enhance, or modify the harvested product qualities, as shown in Appendix 1. 
To carry out the Delphi study, a panel of stakeholders was recruited with expertise in GM issues from various professional sectors such as: crops research and development; arable farming; crop protection; and farm management. Invitations to participate in the study were sent to 212 individuals that had either been engaged in GM research i.e. authors of GMrelated papers in peer-reviewed journals, or who were participants at recent GM-related conferences and technical meetings. These 212 individuals were drawn from a range of institutional backgrounds, with the largest group being university academics (43\%), followed by commercial or government research scientists (20\%) and government officials (20\%). In terms of geographical location, $68 \%$ of the experts were based in Europe, $24 \%$ in North America, and $8 \%$ from other parts of the world.

An explanatory recruitment letter and a one-page questionnaire were e-mailed to the panel of experts in August 2015, and a reminder sent 30 days later, as a means to increase response rate. A total of 51 replies were received, 26 of which were sufficiently complete to be included in the final panel (an effective response rate of 12.3\%). Twenty five responses were unusable, for the following reasons: 10 said they had no relevant knowledge; while 15 declined to participate for other assorted reasons. The response rate of experts working in commercial companies was much higher than for the other categories and so their weight in the final panel is greater than in the original sampling frame.

Whilst the research team would have preferred to have had a Delphi panel of more than 26, we can say, without revealing confidential details of the panel, with a degree of certainty that they were very experienced and possessed expert knowledge of the subject matter under investigation. As such they were both an appropriate and relevant panel for the study. 
223 The second round consultation document was sent out to panel members 60 days after the

224 first mailing. In the second round, each panel member, after being reminded of their own and

225 the panel's average first round estimates, was invited to confirm or amend their original

226 estimates. Of the 26 panel members, 13 replied in the second round, of whom seven made

227 revisions to their first round estimates, while the remainder indicated that they were happy

with their original estimates. For those who did not respond to the second round consultation, we could only assume that they were content to retain their original estimates. Under this assumption, the sample sizes in rounds one and two remained the same.

While more than two iterative consultation rounds are permissible in the Delphi approach, a third estimation round was not considered useful in this case because, as elaborated in the results section below (see Tables 1 and 2), the standard deviation scores associated with the group mean did not change significantly between rounds one and two, suggesting that further significant reductions in the heterogeneity of the estimates would be very unlikely. The estimates that the stakeholders were asked to make related to: (i) the impacts of the GM technologies on crop yield and production costs for input-side traits; and (ii) production costs and potential market price premia for the output-side traits. These estimates were expressed in percentage terms, referenced against those for conventional crops in 2015. Price effects can, therefore, be assumed to be expressed in constant price terms.

The analysis of the impact of these GM technologies on competitiveness was undertaken through application of revised costs i.e. estimates by the consultees of GM impacts on yield, production costs and product prices, as shown in Tables 1 and 2, to models of the cost of crop production for a number of countries using a partial budgeting approach. As data for the full costs of production were available, the impact of the uptake of GM technologies on enterprise 
248 Net Margin was estimable. This relatively simple approach to benefits estimation, which was

249 chosen due to constraints on data availability, was adopted in several past studies which also

250 had the same relatively narrow focus on the estimation of producer economic benefits e.g.

251 Flannery et al. (2004). Data for these representative cost models was derived from official

252 sources i.e. EC directorates and national Departments and Ministries of Agriculture, as well

253 as Government Agencies and commercial providers of benchmarking data. These data

254 represent country-wide 'average' costs of production for non-GM crops in the case-study

255 countries and were derived from representative survey data.

256

$257 \quad$ 3. Results

$258 \quad 3.1 \quad$ Introduction

259 Summary results from the Delphi survey are presented in Table 1 (input-side traits) and Table

2602 (output-side traits). These tables present the mean estimates from the whole panel of

261 consultees for both rounds of consultation, together with a measure of the change in the

262 variability found in these estimates from first to second round i.e. the change in standard

263 deviation (SD) score.

264

265

When SD change scores are generally negative, this implies that the SD of the sample estimates (i.e. the extent of variation between individuals) is decreasing between rounds as the panel closes in on consensus. When the SD change estimates are also small, this suggests that there is relatively little change in the SD estimates between rounds, i.e. convergence has already largely been reached and that further iterations would only yield very small marginal reductions in variation. Statistical testing, using the Paired Comparison Students' $t$ test at the $5 \%$ level, confirmed no significant difference $(p>0.05)$ in the variability between the mean

272 estimates of the two rounds, thus signalling no need for a further round of consultation. 
274 on farmers' costs and the yields obtained.

\begin{tabular}{lcccccccccc}
\hline & \multicolumn{4}{c}{ Mean farmers' cost change (\%) } & \multicolumn{5}{c}{ Mean farmers' yield change (\%) } \\
\hline & $\begin{array}{c}1 \text { 1st } \\
\text { round }\end{array}$ & SD & $\begin{array}{c}\text { 2nd } \\
\text { round }^{2}\end{array}$ & SD & $\begin{array}{c}\text { SD } \\
\text { change }^{1}\end{array}$ & $\begin{array}{c}\text { 1st } \\
\text { round }\end{array}$ & SD & $\begin{array}{c}\text { 2nd } \\
\text { round }^{2}\end{array}$ & SD & $\begin{array}{c}\text { SD } \\
\text { change }^{1}\end{array}$ \\
\hline $\begin{array}{l}\text { Potato - insect } \\
\text { resistant }\end{array}$ & -4.55 & 10.23 & -4.47 & 6.49 & -3.74 & 3.85 & 7.23 & 3.75 & 5.89 & -1.34 \\
$\begin{array}{l}\text { Potato - } \\
\text { pathogen } \\
\text { tolerant }\end{array}$ & -6.38 & 15.58 & -5.89 & 12.63 & -2.95 & 9.26 & 8.56 & 9.14 & 7.58 & -0.98 \\
$\begin{array}{l}\text { Wheat - } \\
\text { drought tolerant }\end{array}$ & 2.55 & 7.81 & 2.38 & 7.33 & -0.48 & 6.85 & 9.40 & 8.00 & 8.32 & -1.08 \\
$\begin{array}{l}\text { Soybean - } \\
\text { herbicide } \\
\text { tolerant }\end{array}$ & -5.75 & 12.85 & -4.93 & 10.52 & -2.33 & 4.28 & 6.34 & 4.07 & 5.04 & -1.30 \\
$\begin{array}{l}\text { Sugarbeet - } \\
\text { herbicide } \\
\text { tolerant }\end{array}$ & -5.66 & 15.70 & -4.70 & 13.18 & -2.52 & 4.45 & 7.04 & 4.19 & 5.89 & -1.15 \\
$\begin{array}{l}\text { Maize - drought } \\
\text { tolerant }\end{array}$ & 0.68 & 8.49 & 0.80 & 7.16 & -1.33 & 6.08 & 8.32 & 6.73 & 7.15 & -1.17 \\
$\begin{array}{l}\text { Maize - } \\
\text { herbicide } \\
\text { tolerant and } \\
\text { insect resistant }\end{array}$ & -5.25 & 13.79 & -4.90 & 12.41 & -1.38 & 6.81 & 9.99 & 6.45 & 8.69 & -1.30 \\
\hline
\end{tabular}

275 Notes:

$276 \quad{ }^{1} \mathrm{SD}$ change is the SD value in the second round minus the value in the first round.

$277 \quad{ }^{2}$ Differences in first and second round mean cost and yield changes were tested for statistical significance using 278 the Students' t test at the 5\% level, and no significant differences were found.

280 Table 2. Experts' views on the likely effect of adopting various GM crops with output traits on farmers' costs and prices for the crops received.

\begin{tabular}{|c|c|c|c|c|c|c|c|c|c|c|}
\hline & \multicolumn{5}{|c|}{ Mean farmers' cost change (\%) } & \multicolumn{5}{|c|}{ Mean farmers' price change (\%) } \\
\hline & $\begin{array}{c}1 \mathrm{st} \\
\text { round }\end{array}$ & SD & $\begin{array}{c}2 \text { nd } \\
\text { round }^{2}\end{array}$ & SD & $\begin{array}{c}\text { SD } \\
\text { change }^{1}\end{array}$ & $\begin{array}{c}1 \mathrm{st} \\
\text { round }\end{array}$ & SD & $\begin{array}{c}2 \text { nd } \\
\text { round }\end{array}$ & SD & $\begin{array}{c}\text { SD } \\
\text { change }^{1}\end{array}$ \\
\hline $\begin{array}{l}\text { Wheat - with } \\
\text { improved } \\
\text { bread-making } \\
\text { properties }\end{array}$ & 5.29 & 5.42 & 5.47 & 5.22 & -0.20 & 6.26 & 4.38 & 6.33 & 4.35 & -0.03 \\
\hline $\begin{array}{l}\text { Wheat - with } \\
\text { reduced levels } \\
\text { of protein } \\
\text { linked to } \\
\text { celiac disease }\end{array}$ & 5.29 & 5.91 & 5.47 & 5.73 & -0.18 & 9.06 & 7.48 & 9.50 & 7.38 & -0.10 \\
\hline $\begin{array}{l}\text { Soybean - } \\
\text { with } \\
\text { improved } \\
\text { nutritional }\end{array}$ & 5.13 & 4.99 & 5.26 & 4.81 & -0.18 & 7.47 & 6.34 & 8.03 & 6.41 & 0.07 \\
\hline
\end{tabular}


profile

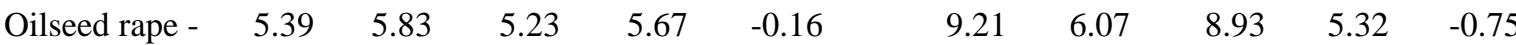

producing

Omega 3 oils

as a dietary

supplement

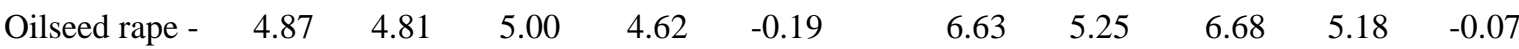

with a lower

lower

saturated fat

content

Notes:

283

${ }^{1} \mathrm{SD}$ change is the SD value in the second round minus the value in the first round.

${ }^{2}$ Differences in first and second round mean cost and price changes were tested for statistical significance using the Students' t test at the 5\% level, and no significant differences were found.

3.2 GM crops with input traits

Input-side traits offer the prospect of financial benefits to farmers from reduced input costs, especially crop protection costs (such as less expenditure on herbicides and pesticides), and increased revenue through improved (or protected) yields. Table 1 shows that the panel costs in the remainder. Costs savings ranged from $4.47 \%$ to $5.89 \%$, a relatively narrow range, with these being somewhat larger in magnitude than the range of expected cost increases i.e. $0.80 \%$ to $2.38 \%$.

The crop-trait combinations offering the largest savings in input costs are pathogen tolerant (PT) potato $(5.89 \%)$ and HT soybean $(4.93 \%)$. At the other end of the spectrum, the panel thought that drought tolerant wheat would raise farmers' costs by $2.38 \%$ due to the fact that there would be no crop protection cost savings to compensate for higher seed costs. The notion of increased production costs for drought tolerance makes perfect sense because, with the possible exception of reducing the need for irrigation, these traits do not replace any inputs, such as sprays, but they may incur higher seed costs. However, these traits may still 
prove financially advantageous if their yield protection benefits, in years of drought, offset the higher seed costs when averaged over the longer term.

305

The highest and lowest anticipated yield improvements (Table 1) are both recorded for potatoes, with IR potato estimated to lift yield by $3.75 \%$, and PT potato by $9.14 \%$. This suggests a panel consensus that current yield losses from insect pests, e.g. Colorado and Flea Beetles, are considerably lower than yield losses from diseases, such as Brown Rot and Late Blight. It is informative to note that most of the recent GM potato trials globally have been for late blight resistance. Drought tolerance is estimated to offer greater potential yield benefits than the average, at $8 \%$ for wheat and $6.73 \%$ for maize. These estimates are high considering that they represent yield protection averaged over a number of years. This strongly suggests the stakeholder view that yield losses in drought years might be catastrophic. Herbicide resistance traits are estimated to offer slightly below average yield improvements for both sugar beet (4.19\%) and soya bean $(4.07 \%)$.

\subsection{GM crops with output traits}

The panel anticipated that all of the crops with output-side traits would incur increased production costs compared to the conventional equivalent (see Table 2). These cost increases would be due, almost in their entirety, to higher seed costs, as biotech companies attempt to recoup their investment in product development. The stakeholder panel provided a pretty narrow range of production cost increases across crop-trait combinations, with a range of just $0.47 \%$. Interestingly, the crop expected to incur the largest increases in production (seed) costs, is wheat, i.e. $5.47 \%$ for both output traits. Here, stakeholders may be factoring in the fact that wheat is a relatively high value crop (per hectare), and so can better support higher 
seed prices than some other crops. At the other end of the scale, the output trait with the smallest increase in production costs was OSR with lower saturated fat content $(5.0 \%)$.

All of the nutritional profile changes identified for GM crops were viewed as being desirable to consumers and, so, all were expected to offer a price premium to the farmer. However, they all represent niche markets so only a fairly small sub-set of farms would be able to grow them. The highest price premium was anticipated for wheat with reduced levels of protein linked to celiac disease (9.5\%), although this would only be a niche market product. Oilseed rape producing Omega 3 oils as a dietary supplement was also expected to offer a substantial premium $(8.93 \%)$. The crop with the lowest estimated premium, by comparison, was wheat with improved bread making properties (6.33\%). This slightly lower premium, in comparison, may be due to the fact that the gains to bread and biscuit makers from the new properties would be only marginal, as this trait would not allow for any new differentiation in the market and so a higher retail price would not be obtainable. However, the panel did not give any 'hard' evidence in this respect.

\subsection{Impact of the 'new' crops on competitiveness}

The significance of these GM technologies i.e. their impact on competitiveness, was explored by comparing GB enterprise production costs and market returns (i.e. sales value without subsidy), both with and without GM, to equivalent non-GM production in selected EU countries. Figure 1 shows the impact of GM adoption on competitiveness, as expressed by market returns and net margin for output-side traits, and operating costs and net margin for input-side traits. The adopter country (i.e. where GM technologies have been applied) is GB agriculture for six out of eight crop-trait combinations, but France had to be used in the two grain maize cases, as grain maize production does not occur in GB. 
353 Figure 1 suggests that, assuming widespread adoption, the selected GM traits could improve 354 the competitive position of GB agriculture compared to non-adopting EU counterparts. The way in which this improvement in competitiveness is achieved varies according to trait. For input-side traits, competitiveness is improved by reducing production costs. For example, in the case of potatoes, current GB production costs are roughly equivalent to those in the Netherlands. However, the adoption of GM pest control technologies for this crop i.e. HT and pathogen tolerance (PT) would reduce average GB production costs by $4.5 \%$ and $5.9 \%$ respectively (see Table 1) to a level significantly below that in the Netherlands. If these cost savings could be passed on to consumers in the form of lower prices, GB potatoes could, perhaps, compete for market share in the Netherlands, despite the additional transport costs.

In the case of output traits, the panel thought that costs of production are, more often than not, expected to increase, as in the case of OSR with enhanced Omega 3 content, where production costs were projected to rise by $5.2 \%$ (see Table 2). Whilst this would lead to higher consumer prices if consumers placed a higher value on this 'enhanced' product, they would be willing to pay these higher prices. If the monetised value that consumers placed on the enhanced product was greater than the production cost increases, then a producer (price) surplus would be available, as indeed is projected in this case, with an expected rise in producer price of $8.9 \%$ (see Table 2). Competitive advantage would also be improved through gaining access to a niche market that non-adopters could not exploit.

Figure 1. Impact of the uptake of selected GM technologies on the competitiveness of crop production in Great Britain and various EU countries. 


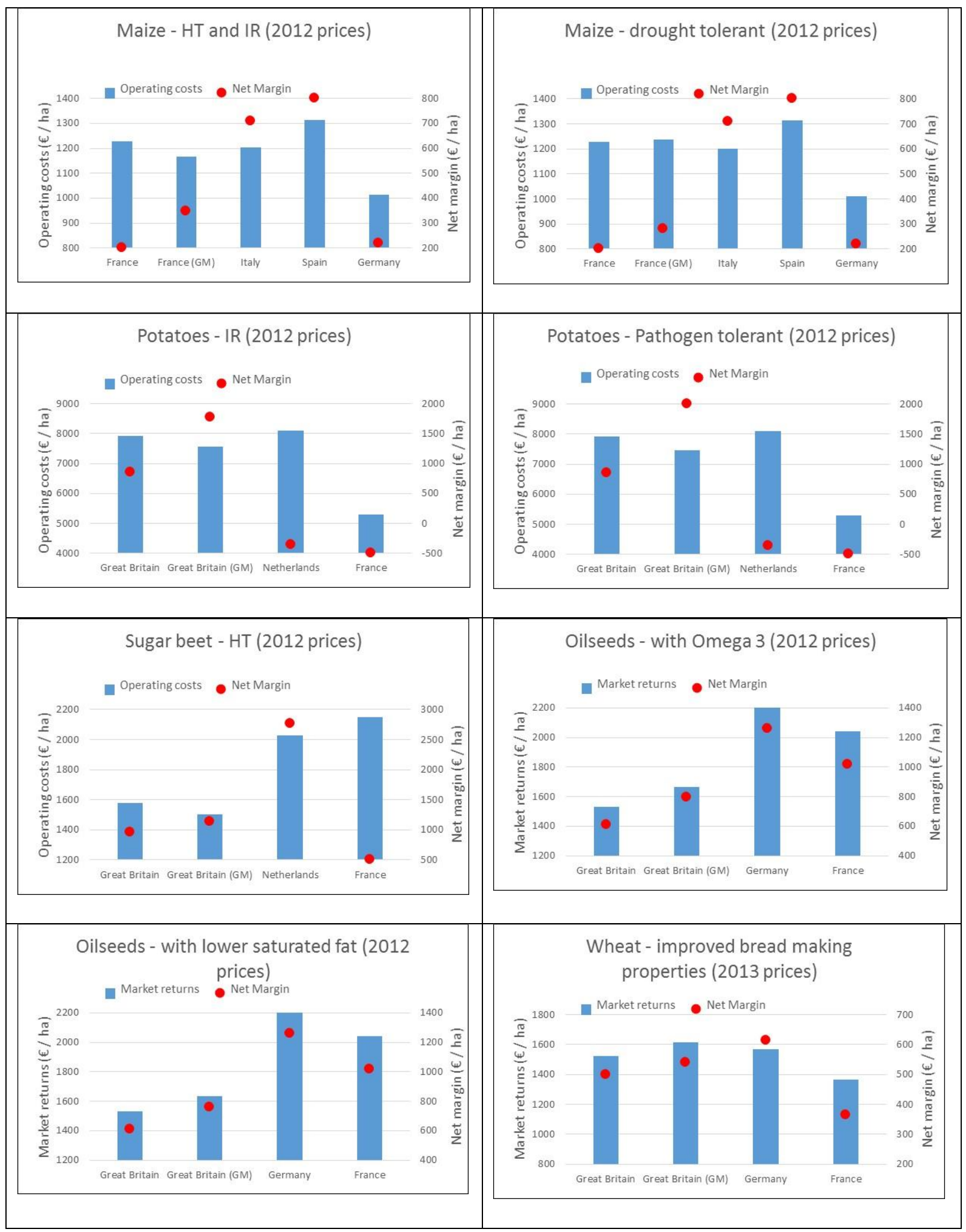

379 Sources: EC (2016b); AHDB (2015); Defra (2013); Rezbova et al. (2013); USDA (2012); AgriBenchmark (2016); and EC (2012). 
Note: Wheat and grain maize enterprise data are based on FADN whole-farm data for farms specialising in those crops.

Note: Potato prices are based on a 3-year average centred on 2012 to smooth out extreme annual variation.

Note: Data originally denominated in $£$ Sterling have been converted to Euros, assuming an exchange rate of

Note: NL sugar beet production costs (2012) are assumed to be the same as in DE.

Note: The average EU rapeseed price (2012) has been used for DE and FR.

Competitiveness is also indirectly improved, for all traits considered here, through increased profit (i.e. Net Margin). More profit means more capital is available for investment in: technological innovation through new machinery purchases; land purchases to spread fixed costs; or through enhanced training and advisory services. These investments drive increases in technical and managerial efficiency, thereby securing further improvements in competitiveness. Improvement in competitiveness of this kind is best exemplified by wheat with improved bread-making properties (see Figure 1). GB adoption of this GM technology would increase wheat production costs by $5.5 \%$ i.e. rising above average costs in Germany, but would elevate profits by $8.1 \%$ through an increased price premium (of $6.3 \%$ ), thereby enhancing the prospect of additional future UK investments leading to improvements in efficiency.

3.5 Identification of other crop-trait GM combinations that might become available The selection of crop-trait combinations used in the study reported here was made on the basis that the technologies were either already in the market, or well along the development pipeline and would also offer potentially significant benefits to EU farmers or consumers. These particular crop-trait combinations were chosen because they captured the most important trait types, across a range of major crops. To guard against the possibility that important crop-trait combinations had been omitted from the Delphi consultation, panel 
members were asked to suggest any such alternatives that also met the selection criteria.

Only a small number of GM crop-trait combinations were suggested by the panel, these being dominated by output-side traits i.e. various types of biofortification. Most of these output-side traits would supply niche markets, which are by nature, small. Therefore, there would only be very limited opportunities to tap into these markets to secure a price premia. Such traits, therefore, offer only modest benefits for the broader farming sector and wider society. In light of this it is, perhaps, not damaging to the analysis presented here that some GM traits of this type have been omitted. Of course, some output-side traits, for example vitamin fortification, might not be confined to niche markets but could, in theory, displace all conventional production. However, while the potential market for such traits is, in theory, very large, the scale of the benefits to both farmers and wider society within the EU are likely to be small. There are two reasons for this. First, when a GM crop displaces its conventional equivalent, even if some additional societal benefit is being supplied, market prices tend to drop to the same floor as in the former conventional market. Second, in any developed country where diets are already nutritious and where many fortified processed products already exist, the price premium for a biofortified commodity would be small, reflecting the small marginal societal gain.

A minority of the panel of stakeholders, when asked to identify prospective GM technologies that were not included by our review, pointed away from traditional GM technologies instead to the products of new plant breeding techniques (NPBTs), such as CRISPR, which do not use transgenesis. Although relatively new, techniques such as CRISPR are already being hailed (for example, see Belhaj et al, 2013; and Ledford, 2015) as the future industry standard tool for biotechnology, thereby likely to supplant GM in plant breeding. While the status of these NPBTs are currently still being debated by advisory bodies and regulatory authorities in 
the EU (Tagliabue, 2016), the hope is that because they produce plant gene modifications that are indistinguishable from both conventional breeding and chemical and physical mutagenesis, they will be excluded from the scope of GM legislation such as Directive 2001/18/EU on Deliberate Release of Genetically Modified Organisms. This would make releases of such crops to the EU market much more routine.

\section{Discussion and conclusions}

Our choice of a stakeholder consultation approach for generating estimates of likely yield, cost and revenue changes resulting from future EU (or UK) adoption of GM crops allowed a nuanced transfer of data from non-EU settings into the EU context where crop-trait combinations have already been developed and has also allowed for the generation of 'novel' data where crop-trait combinations are still in development. The extent of the challenge facing the consultees in transferring data from non-EU settings depended on several factors, including perceptions of whether there are likely to be differences in seed costs, or agronomic differences between the EU and non-EU settings that had to be accounted for, plus differences in disease pressure and pest management practice.

Another important consideration that consultees had to account for was the likely costs associated with required co-existence measures in adopter countries, as these could impact considerably on production costs. The specific measures that might be put in place in the adopter countries for individual crops could not, perhaps, be easily anticipated, so it is not exactly clear how consultees handled this issue. However, it is likely that reference would have been made to the impact of co-existence measures on production costs in countries that had already adopted similar GM technologies. It is also worth pointing out that the existence of co-existence measures in these non-EU countries has not acted either as a barrier to rapid 
uptake, nor significantly eroded the financial benefits that the technology confers (see, for example, Furtan et al, 2007), including the case of GM maize in Spain and Portugal.

The cross-country analysis reported here provides a useful indicator of the impacts that GM crop adoption would have on national competitiveness. However, it should be recognised that this analysis presents a somewhat simplified picture of possible future adoption decisions. First, the analysis assumes near complete uptake of these GM technologies in the adopter country. While this must be a reasonable assumption for some of these GM technologies based on historic observation, for example PT potatoes would likely be widely adopted as all growers could benefit. However, this might not be the reality for some crop-trait combinations, for example where the GM technology targets a particular pest problem that is not present in all regions within a country. A historical example of this would be the adoption of IR maize in Portugal, where uptake has been confined to regions where

European/Mediterranean Corn Borer presents a significant commercial risk (Jones et al, 2017). For crops with limited potential for market penetration, for example DT maize, the results of the competitiveness analysis should not be interpreted as indicating the impacts for the competitiveness of the countries as a whole.

Second, the data used in the representative cost models are reflective of the central tendency in each case-study country. In reality, a wide distribution of production costs exists in each country, due to diversity in farmers' management ability, agronomic factors and geographic location. This means that changes to the competitive advantage resulting from GM adoption would not be uniformly experienced amongst producers in any country. 
482 Third, the consultees' estimates of GM impacts in costs and yields are themselves also

483

484

485

486

487 measures of central tendency, obscuring a likely broad range of impacts experienced by individuals, where some, due to their particular circumstances, may not receive significant benefits from the technology. Finally, the possibility must be considered that the consultees, in considering the impacts of the GM technologies on production costs, did not properly factor in possible increases in costs associated with some potential negative externalities of adoption of GM technologies, such as increase in pest resistance through the use of HT or IR events (Green \& Owen, 2011; Brookes, 2014). In such circumstances, additional management actions are required to control the problem, perhaps involving applications of alternative pesticides requiring more sprayer passes, or other approaches to pest control, such as changed rotations, or use of deep mechanical tillage.

Whilst resistance problems can be controlled by careful use of conventional management techniques, the need to undertake them can remove some, or all, of the cost saving benefits from the use of the technology (Green \& Owen, 2011). Numerous other studies have claimed a range of environmental and social dis-benefits arising from the widespread adoption of GM technologies, such as gene-flow to non-GM crops (Mallory-Smith \& Zapiola, 2008) and wild relatives (Warwick, et al., 2008; Reichman, et al., 2006), damage to wildlife (Garcia \& Altieri, 2005) and even economic risks to non-GM producers through adventitious contamination (Blakeney, 2016). There is insufficient space to critique these studies and claims here, although it is worth noting that several authors have cogently argued that the environmental and socio-economic benefits of GM crops far outweigh any negative externalities (Brookes \& Barfoot, 2016). Whilst this lack of detailed critique may seem unsatisfying to some, it should be pointed out that for the analysis here there is the requirement to do so, as the focus of the study reported here is on the impacts of adoption of 
507 GM technologies in the EU on potential producer surplus, rather than consumer, or wider societal surplus.

The historic policy environment in the EU has resulted in an effective moratorium on GM releases to the environment. With most consumers, campaigning groups and politicians across the EU remaining largely hostile to the production of GM crops and the consumption of their products, it is understandable that many of the stakeholders consulted were of the view that the current informal moratorium on GM authorisations would remain in place for the foreseeable future. While the GM policy environment has changed in the last few years, there is still great uncertainty over whether this will make GM authorisations more likely, as many states are likely to execute the opt-outs permissible under the new legislation. For example, it is already known that 19 Member States had applied for the opt-out prior to the 3 October 2015 deadline for applications to the Commission, including: Germany, France, Italy, Austria, Greece, Hungary, Latvia, Lithuania and Poland (New Scientist, 2015). Additionally, even if authorisations begin to flow, it is not known whether GM crops would actually be accepted into these national markets by retailers and consumers.

The uncertainty revealed here by our consultation over the future market and policy environment will, of course, do little to change the attitudes of biotech companies towards investment in biotechnologies targeted at EU agronomic conditions or, indeed, those seeking authorisations for GM crops to be grown in the EU. If this generally pessimistic stakeholder outlook is a harbinger of restrictive future EU policies, and is a disincentive to biotech companies to invest in GM crops targeted at EU agriculture, then the benefits associated with GM crops identified here must be viewed, in essence, as benefits that will be foregone by the great majority of EU farmers. 
533 In terms of the scale of these benefits foregone, the study reported here has shown that the

534

535

536

537

538

539

540

541

542

543

544

545

546

547

548

549

550

551

552

553

554

555

556

competitiveness of the agricultural sector in EU Member States could very well be improved

by adoption of GM crops. However, these improvements, when averaged over all farmers in a country, would still be relatively small-scale, to the extent that existing large-scale natural advantage, resulting from relatively durable macro-economic or environmental conditions, is very unlikely to be overturned. For example, the adoption of HT/IR grain maize in France would, in terms of country-wide averages, overturn the current small competitive advantage that Italy holds, but would do little to eliminate the much more significant competitive advantage (resulting from lower costs of production) held by Germany. Adoption of GM crops would, therefore, not be a game changer for countries with high production costs, although they would, based on the evidence generated in the study reported here, make a positive contribution with respect to competitiveness in any country that adopts them.

\section{Acknowledgement}

The work reported here was carried out as part of the EU-funded AMIGA Project

(www.amigaproject.eu). We are also grateful to the expert panel members who kindly took the time to take part in our study,

\section{References}

AHDB, 2015. Cost of production for processing potatoes in North West Europe. Agriculture and Horticulture Development Board, Kenilworth, Warwickshire, UK.

AgriBenchmark, 2016. Cash Crop. http://www.agribenchmark.org/cash-crop.html (Accessed: November, 2016). 
558 APHIS, 2015. Biotechnology: petitions for determination of non-regulated status.

Aschonitis, V. G., Lithourgidis, A.S., Damalas, C.A., Antonopoulos, V.Z., 2013. Modelling yields of non-irrigated winter wheat in a semi-arid mediterranean environment based on drought variability. Exp. Agr., 49, 448-460

564

Baktavachalam, G. B., Delaney, B., Fisher, T.L., Ladics, G.S., Layton, R.J., Locke, M.E.,

Schmidt, J., Anderson, J.A., Weber, N.N., Herman, R.A., Evans, S.L., 2015. Transgenic maize event TC1507: global status of food, feed, and environmental safety, GM Crops \& Food: Biotechnology in Agriculture and the Food Chain, 6, 80-102.

569

570

Batista, C., Barros, L., Carvalho, A.M., Ferreira, I.C.F.R., 2011. Nutritional and nutraceutical

571 potential of rape (Brassica napus L. var. napus) and "tronchuda" cabbage (Brassica oleraceae L. var. costata) inflorescences. Food Chem. Toxicol., 49, 1208-1214.

573

574 Belhaj, K., Chaparro-Garcia, A., Kamoun, S., Nekrasov, V., 2013. Plant genome editing 575 made easy: targeted mutagenesis in in model and crop plants using the CRISPR/Cas system. 576 Plant Methods, 9, 39.

Blakeney, M., 2016. Organic versus GM Agriculture in the Courtroom in Australia and the 579 United States. AgBioForum, 19, 184-197.

580 
581

582

583

584

585

586

587

588

589

590

591

592

593

594

595

596

597

598

599

600

601

602

603

604

Brookes, G., 2003. The farm level impact of using Roundup Ready soybeans in Romania.

Graham Brookes, UK.

www.bioportfolio.com/pdf/FarmlevelimpactRRsoybeansRomaniafinalreport.pdf

Brookes, G. 2007. The benefits of adopting genetically modified, insect resistant (Bt) maize in the European Union (EU): first results from 1998-2006 plantings. PG Economics Ltd, England.

Brookes, G., 2014. Weed control changes and genetically modified herbicide tolerant crops in the USA 1996-2012. GM Crops \& Food, 5, 321-332.

Brookes, G., Barfoot, P., 2016. GM crops: global socio-economic and environmental impacts 1996-2014. PG Economics Ltd., Dorchester, UK.

Carpenter, J.E., 2010. Peer-reviewed surveys indicate positive impact of commercialized GM crops. Nature Biotechnology, 28, 319-321.

Cunha, A., Swinbank, A., 2009. Exploring the determinants of CAP reform: a Delphi survey of key decision-makers. J. Common Mark. Stud., 47, 235-261.

Dalkey, N.C., 1972. The Delphi method: an experimental study of group opinion. In: Dalkey, N.C., Rourke, D.L., Lewis, R., Snyder, D. (Eds.) Studies in the quality of life: Delphi and decision-making (pp 13-54). Lexington Books, Lexington, MA. 
605

606

607

608

609

610

611

612

613

614

615

616

617

618

619

620

621

622

623

624

625

626

627

628

Dalkey, N.C., Helmer, O., 1963. An experimental application of the Delphi method to the use of experts. Manage. Sci., 9, 458-467.

Defra (2013) Agriculture in the UK 2012. Defra, London.

Demont, M. and Tollens, E., 2004. First impact of biotechnology in the EU: Bt maize adoption in Spain. Ann. appl. Biol., 145, 197-207.

Demont, M., Dillen, K., Mathijs, E., Tollens, E., 2007. GM Crops in Europe: How Much Value and for Whom? EuroChoices, 6(3), 46-53.

Demont, M., Daems, W., Dillen, K., Mathijs, E., Sausse, C., Tollens, E., 2008. Regulating coexistence in Europe: Beware of the domino-effect! Ecological Economics, 64, 683-689.

De Steur, H., Blancquaert, D.,Strobbe, S., Lambert, W., Gellynck, X., Van Der Straeten, D., 2015. Status and market potential of transgenic biofortified crops, Nat. Biotechnol., 33, 2529.

Dillen, K., Demont, M., Tollens, E., 2009. Global welfare effects of GM sugar beet under changing EU sugar policies. AgBioForum, 12, 119-129.

Dillen, K., Demont, M., Tillie, P., Cerezo, E.R., 2013. Bred for Europe but grown in America: the case of GM sugar beet. New Biotechnology, 30, 131-135. 
629

630

631

632

633

634

635

636

637

638

639

640

641

642

643

644

645

646

647

648

649

650

651

652

Dupras, J., Patry, C., Tittler, R., Gonzalez, A., Alam, M., Messier, C., 2016. Management of vegetation under electric distribution lines will affect the supply of multiple ecosystem services. Land Use Pol., 51, 66-75.

EC, 2012. EC Commodity Price Data, June 2012 Edition. European Commission, 1 August 2012.

EC, 2016a. EU Register of Authorised GMOs.

http://ec.europa.eu/food/dyna/gmregister/indexeu.cfm Accessed 4 March 2016.

EC, 2016b. EU cereal farms report based on 2013 FADN data. European Commission, Directorate General for Agriculture and Rural Development, Brussels, June 2016.

European Parliament and Council, 2015. Directive (EU) 2015/412 of 11 March 2015 amending Directive 2001/18/EC as regards the possibility for the Member States to restrict or prohibit the cultivation of genetically modified organisms (GMOs) in their territory. (OJ) L $68 / 1$.

FAO, 2015. FAO GM Foods Platform. http://www.fao.org/food/food-safety-quality/gmfoods-platform/browse-information-by/commodity/en/ Accessed 1 March 2016.

Farooq, M., Hussain, M., Siddique, K.H., 2014. Drought stress in wheat during flowering and grain-filling periods, Crit. Rev. Plant Sci., 33, 331-349. 
653 Fearne, A., 1986. Forecasting agricultural policy decisions in the European Community. PhD

654 Thesis, University of Newcastle-upon-Tyne.

655

656 Ferrero, R., Lima, M., Gonzalez-Andujar, J.L., 2014. Spatio-temporal dynamics of maize

657 yield water constraints under climate change in Spain. PLoS ONE, 9, e98220.

658

659 Fernandez-Cornejo, J., Wechsler, S., Livingston, M., Mitchell, L., 2014. Genetically

660 engineered crops in the United States. USDA-ERS Economic Research Report, 162.

661

662 Flannery, M-L., Thorne, F.S., Kelly, P.W., Mulline, E., 2004. An Economic Cost-Benefit

663 Analysis of GM Crop Cultivation: An Irish Case Study. AgBioForum, 7(4), 149-157.

664

665 Furtan, W.H., Guzel, A., Weseen, A.S., 2007. Landscape clubs: co-existence of genetically

666 modified and organic crops. Can. J. Agr. Econ. 55, 185-195

667

668 Garcia, M.A., Altieri, M.A., 2005. Transgenic Crops: Implications for Biodiversity and

669 Sustainable Agriculture. Bulletin of Science, Technology \& Society, 25, 335-353.

670

671 Gil-Humanes, J., Pistón, P., Tollefsen, S., Sollid, L.M., Barro, F., 2010. Effective shutdown

672 in the expression of celiac disease-related wheat gliadin T-cell epitopes by RNA interference.

673 Proceedings of the National Academy of Sciences, 107, 17023-17028.

674

675 Glass, J.H., Scott, A.J., Price, M.F., 2013. The power of the process: co-producing a

676 sustainability assessment toolkit for upland estate management in Scotland. Land Use Policy, $677 \quad 30,254-265$. 
679 Graybosch, R. A., Seabourn, B., Chen, Y.R., Blechl, A.E., 2013. Transgenic enhancement of

680

681

682

683

684

685

686

687

688

689

690

691

692

693

694

695

696

697

698

699

700 high-molecular-weight glutenin subunit 1Dy10 concentration: effects in wheat flour blends and sponge and dough baking. Cereal Chem., 90, 164-168.

Green, J.M., Owen, M.D.K., 2011. Herbicide-Resistant Crops: Utilities and Limitations for Herbicide-Resistant Weed Management. J Agric Food Chem., 59, 5819-5829.

Haesaert, G., Vossen, J.H., Custers, R., De Loose, M.., Haverkort, A., Heremans, Hutten, R., Kessel, G., Landschoot, S., Van Droogenbroeck, B., 2015. Transformation of the potato variety Desiree with single or multiple resistance genes increases resistance to late blight under field conditions. Crop Prot., 77, 163-175.

Hefferon, K. L., 2015. Nutritionally enhanced food crops; progress and perspectives. Int. J. Mol. Sci., 16, 3895-3914.

House of Commons Science and Technology Committee, 2015. Advanced genetic techniques for crop improvement: regulation risk and precaution. Fifth Report of Session 2014-15. HMSO, London.

Hsu, C-C., Sandford, B.A., 2007. The Delphi technique: making sense of consensus. Pract. Assess., Res. Eval., 12, 1-8. 
701

702

703

704

705

706

707

708

709

710

711

712

713

714

715

716

717

718

719

720

721

722

723

724

725

Ilbery, B., Maye, D., Kneafsey, M., Jenkins, T., Walkley, C., 2004. Forecasting food supply chain developments in lagging rural regions: evidence from the UK. J. Rural Stud., 20, 331244

James C., 2014. Global status of commercialized biotech/GM crops: 2014. ISAAA Brief No.49. ISAAA, Ithaca, NY.

Jo, K.-R., Kim, C.J., Kim, S.-J., Kim, T.-Y., Bergervoet, M., Jongsma, M.A., Visser, R.G., Jacobsen, E., Vossen, J.H., 2014. Development of late blight resistant potatoes by cisgene stacking, BMC Biotechnology, 14, 50.

Jones, P J., Quedas, M.F., Tranter, R.B., Trindade, C.P., 2017. Exploring the Constraints to Further Expansion of GM Maize Production in Portugal. AgBioForum, (In Press).

JRC, 2015. EU Register of Authorised GMOs.

http://ec.europa.eu/food/dyna/gm_register/index_en.cfm (accessed 4 March, 2016)

Kathage, J., Rodríguez-Cerezo, E., Gómez-Barbero, M., 2016. Providing a Framework for the Analysis of the Cultivation of Genetically Modified Crops: The First Reference Document of the European GMO Socio-Economics Bureau. AgBioForum, 19(2), 112-119.

Kenyon, W., Hill, G., Shannon, P., 2008. Scoping the role of agriculture in sustainable flood management. Land Use Policy, 25, 351-360.

Ledford, H., 2015. CRISPR, the disruptor. Nature, 522, 20-24. 
727 Linstone, H.A., Turoff, M., 1975. Introduction. In: Linstone, H.A., Turoff, M. (Eds) The

728 Delphi method: techniques and applications (pp 3-12). Addison-Wesley Publishing

729 Company, Reading, MA.

730

731 Mallory-Smith, C., Zapiola, M., 2008. Gene flow from glyphosate-resistant crops. Pest

732 Management Science, 64, 428-440.

733

734 Martino, J.P., 1993. Technological forecasting for decision making. $3^{\text {rd }}$ edition. McGraw-Hill, 735 Columbus, Ohio, USA.

736

737 Menrad, K., Agrafiotis, D., Enzing, C.M., Lemkow, L., Terragni, F., 1999. Future impacts of 738 biotechnology on agriculture, food production and food processing. Springer Verlag, 739 Heidelberg.

740

741 MAGRAMA (Ministry of Agriculture, Food and Environment for Spain), 2014.

742

http://www.magrama.gob.es/es/calidad-y-evaluacion-

743

ambiental/temas/biotecnologia/ESTIMACI\%C3\%93N_DE_LA_SUPERFICIE_TOTAL_DE

744

_VARIEDADES_OMG_CULTIVADAS_EN_ESPA\%C3\%91A_tcm7-345334.pdf

745 (Accessed 4 March 2016)

746

747 Ministry of Agriculture and Sea (of Portugal), 2014. http://www.drapal.min-

748

agricultura.pt/drapal/images/servicos/ogm/DADOS_NACIONAIS_2014_setembro.pdf

749 (Accessed, 4 March, 2016)

750 
752 Reichman, J.R., Watrud, L.S., Lee, E.H., Burdick, C.A., Bollman, M.A., Storm, M.J., King,

753 G.A., Mallory-Smith, C., 2006. Establishment of transgenic herbicide-resistant creeping

754 bentgrass (Agrostis stolonifera L.) in nonagronomic habitats. Mol Ecol., 15, 4243-55.

755

756 Rezbova, H., Belova, A., Skubna, O. (2013) Sugar beet production in the EU and their future 757 trends. Agris on-line Papers in Economics and Informatics, 5(4), 165-178.

758

759

Ricroch, A. E., Hénard-Damave, M. C., 2016. Next biotech plants: new traits, crops, developers and technologies for addressing global challenges. Crit. Rev. Biotechnol., 36.

761

762

Ruffo, M. L., Gentry, L.F., Henninger, A.S., Seebauer, J.R., Below, F.E., 2015. Evaluating management factor contributions to reduce corn yield gaps, Agron. J., 107, 495-505.

764

Scott, A.J., 2011. Focussing in on focus groups: effective participative tools or cheap fixes for land use policy? Land Use Pol., 28, 684-694.

767

768

Sowa, I., Wójciak-Kosior, M., Strzemski, M., Dresler, S., Szwerc, W., Blicharski, T.,

Szymczak, G.Y., Kocjan, R., 2014. Biofortification of soy (Glycine max (L.) Merr.) with strontium ions, J. Agr. Food Chem., 62, 5248-5252.

Stebler, N., Schuepbach-Regula, G., Braam, P., Falzon, L.C., 2015. Use of a modified Delphi panel to identify and weight criteria for prioritization of zoonotic diseases in Switzerland. Pre. Vet. Med., 121, 165-169. 
782

783

792

793

794

795

796

797

798

799

800

Stein A., Rodríguez-Cerezo E., 2009. The global pipeline of new GM crops: implications of asynchronous approval for international trade. JRC Technical Report EUR 23486. EC Joint Research Centre, Seville, Spain.

Tagliabue, G., 2016. European incoherence on GMO cultivation versus importation. Nature Biotechnology, 34, 694-5.

Tolk, J. A., Evett, S.R., Xu, W., Schwartz, R.C., 2016. Constraints on water use efficiency of drought tolerant maize grown in a semi-arid environment. Field Crop Res., 186, 66-77.

USDA, 2012. GAIN Report No. E70018, EU27 Sugar Annual Report. USDA Foreign Agricultural Service, 27 April 2012.

Warwick, S.I., Legere, A., Simard, M.J., James, T., 2008. Do escaped transgenes persist in nature? The case of an herbicide resistant transgene in a weedy Brassica rapa population. Molecular Ecology, 17, 1387-1395.

Yadav, D., Shavrukov, Y., Bazanova, N., Chirkova, L., Borisjuk, N., Kovalchuk, N., Ismagul, A., Parent, B, Langridge, P., Hrmova, M., Lopato, S., 2015. Constitutive overexpression of the TaNF-YB4 gene in transgenic wheat significantly improves grain yield. J. Exp. Bot., 66, 6635-6650.

Young, S.J., Jamieson, L.M., 2001. Delivery methods of the Delphi: a comparison of two approaches. J. Park Recreat. Admi., 19, 42-58. 
Appendix 1. The various GM crops, and their traits, shortlisted for the Delphi survey.

\begin{tabular}{|c|c|c|c|c|c|c|}
\hline Crop & Phenotype class & $\begin{array}{l}\text { Year of first field } \\
\text { test notification } \\
\text { (APHIS) }\end{array}$ & IP owners (trials in last 5 years) & $\begin{array}{l}\text { No. of } \\
\text { trials in } \\
\text { last } 5 \\
\text { years }\end{array}$ & $\begin{array}{l}\text { USDA unregulated } \\
\text { status granted (and } \\
\text { IP owners)? }\end{array}$ & $\begin{array}{l}\text { Sources used to } \\
\text { identify suitability } \\
\text { for EU agriculture }\end{array}$ \\
\hline Maize & Drought tolerance & Unknown & $\begin{array}{l}\text { Pioneer Hi-Bred International Inc; } \\
\text { Monsanto. }\end{array}$ & $>15$ & $\begin{array}{l}\text { Yes } \\
\text { Pioneer Hi-Bred } \\
\text { International Inc.; } \\
\text { Monsanto; } \\
\text { BASF; } \\
\text { Syngenta. } \\
\end{array}$ & $\begin{array}{l}\text { Ferrero } \text { et al (2014) } \\
\text { Tolk et al (2016) }\end{array}$ \\
\hline Maize & HT-IR stacked & $\begin{array}{l}1992 \\
\text { Pioneer Hi-Bred } \\
\text { International Inc }\end{array}$ & $\begin{array}{l}\text { Monsanto \& Monsanto Europe, S.A.; } \\
\text { Syngenta Crop Protection LLC; } \\
\text { Pioneer H-Bred International Inc; } \\
\text { Dow AgroSciences LLC; } \\
\text { Genective SA; } \\
\text { Bayer CropScience; } \\
\text { Genective SA; } \\
\text { Instituto Nacional de Investigación y } \\
\text { Tecnología Agraria y Alimentaria } \\
\text { (INIA). }\end{array}$ & $>15$ & $\begin{array}{l}\text { Yes } \\
\text { Monsanto; } \\
\text { Pioneer Hi-Bred } \\
\text { International Inc.; } \\
\text { Syngenta; } \\
\text { Aventis; } \\
\text { Novartis Seeds. }\end{array}$ & $\begin{array}{l}\text { Baktavachalam et al } \\
\text { (2015) } \\
\text { Ruffo et al (2015) }\end{array}$ \\
\hline Potato & IR & $\begin{array}{l}1990 \\
\text { Monsanto }\end{array}$ & Michigan State University. & $>15$ & $\begin{array}{l}\text { Yes } \\
\text { Monsanto; } \\
\text { Frito Lay; } \\
\text { USDA; } \\
\text { Calgene. }\end{array}$ & $\begin{array}{l}\text { Haeseart et al (2015) } \\
\text { Jo et al (2014) }\end{array}$ \\
\hline
\end{tabular}




\begin{tabular}{|c|c|c|c|c|c|c|}
\hline Crop & Phenotype class & $\begin{array}{l}\text { Year of first field } \\
\text { test notification } \\
\text { (APHIS) }\end{array}$ & IP owners (trials in last 5 years) & $\begin{array}{l}\text { No. of } \\
\text { trials in } \\
\text { last } 5 \\
\text { years }\end{array}$ & $\begin{array}{l}\text { USDA unregulated } \\
\text { status granted (and } \\
\text { IP owners)? }\end{array}$ & $\begin{array}{l}\text { Sources used to } \\
\text { identify suitability } \\
\text { for EU agriculture }\end{array}$ \\
\hline $\begin{array}{l}\text { Sugar } \\
\text { beet }\end{array}$ & HT & $\begin{array}{l}2004 \\
\text { Syngenta }\end{array}$ & $\begin{array}{l}\text { Betaseed inc; } \\
\text { Ses Vanderhave NV; } \\
\text { Syngenta Crop Protection AG; } \\
\text { Plant Production Research Center } \\
\text { Piestany, Bratislavska cesta; } \\
\text { KWS SAAT AG; } \\
\text { SESVANDERHAVE N.V.; } \\
\text { Monsanto Europe SA. }\end{array}$ & $5-10$ & $\begin{array}{l}\text { Yes } \\
\text { American Crystal } \\
\text { Sugar Company; } \\
\text { Syngenta; } \\
\text { Betaseed; } \\
\text { Ses Vanderhave NV. }\end{array}$ & Dillen et al (2013) \\
\hline
\end{tabular}




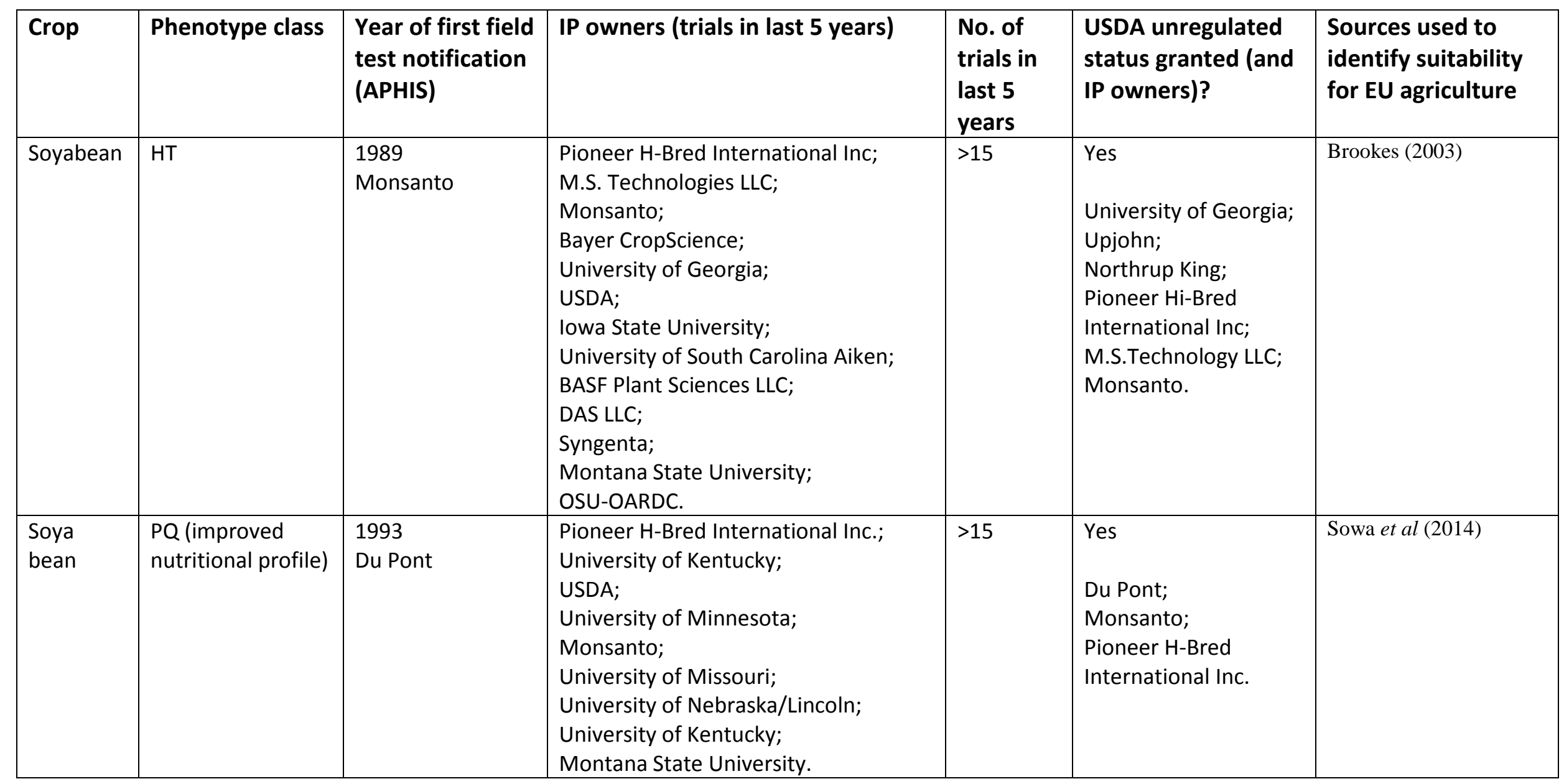




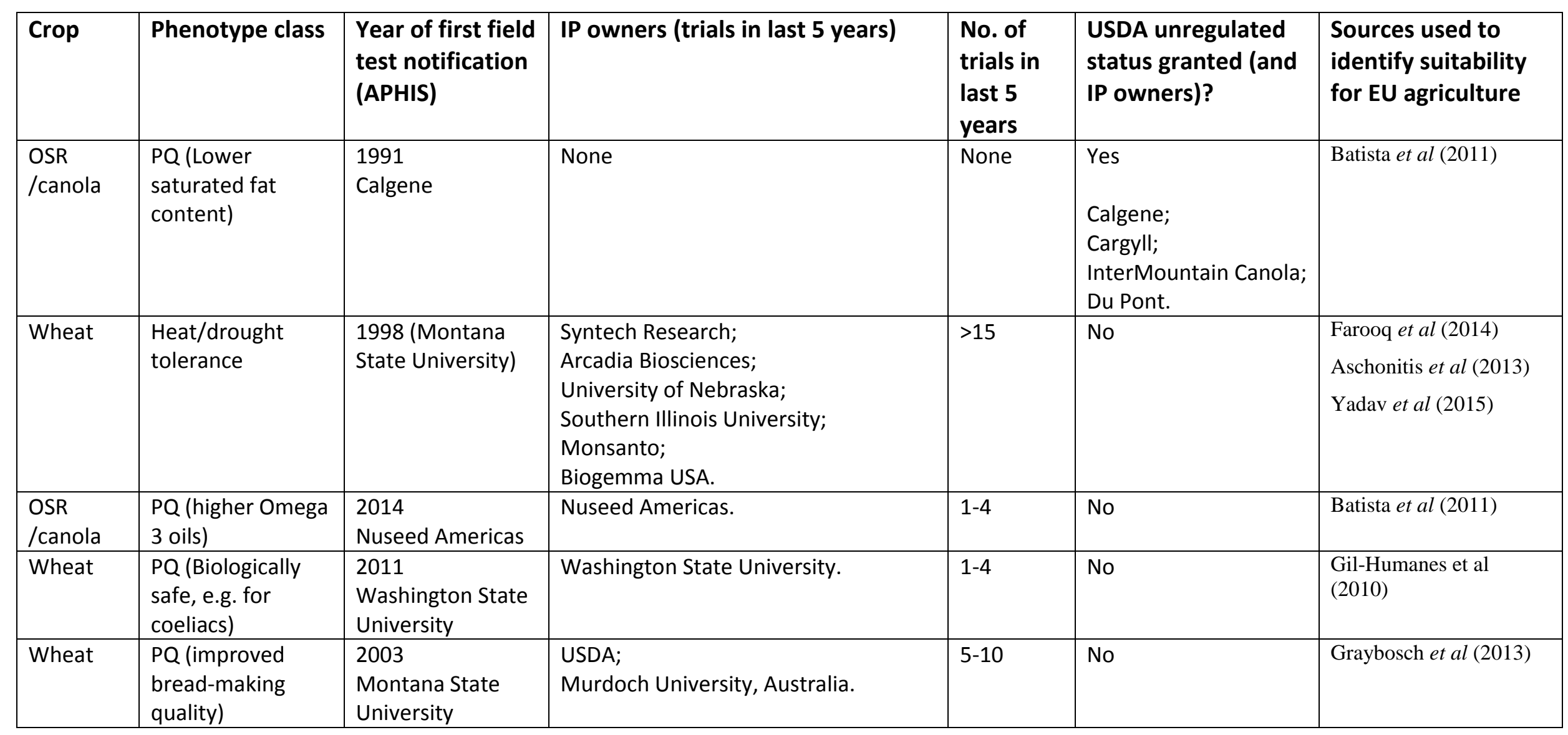

